\title{
炭素緎維シートにより修復された 炭素短繊維補強コンクリート造円筒殼の耐力 \\ STRENGTH OF CARBON FIBER CHIP REINFORCED CONCRETE CYLINDRICAL SHELLS RETROFITTED WITH CARBON FIBER SHEETS
}

\author{
田中正史*，眞下和彦** \\ Masafumi TANAKA and Kazuhiko MASHITA
}

\begin{abstract}
The strength and cracking patterns of retrofitted carbon fiber chip reinforced concrete cylindrical shells were investigated, both experimentally and numerically. Three kinds of retrofits to the damaged shells were adopted in this paper: Precut retrofit, filler retrofit and sheeting retrofit. Precut retrofit was defined as the method worked to cut the region adjacent to the damaged boundary to be smoothed in order to avoid the stress concentration. Filler retrofit was defined as the method made by filling the region with the non-contracted mortar after applying by pecut retrofit. Sheeting retrofit was defined as the method worked on the surface of the region covered with the carbon fiber sheets after applying by filler retrofit. The concrete was artificially damaged before it was evaluated by a loading experiment using a one-point concentrated load, and the retrofit applied to the damaged shells was realized by the three kinds of retrofitting methods described above. In the experimental study, a static point load was applied perpendicularly onto the retrofitted cylindrical shell specimens until the cracking pattern was obtained by applying the maximum force. In the numerical analysis, nonlinear finite element analysis to model the effects of concrete cracking and tension stiffening was applied. The strength and cracking patterns of the retrofitted carbon fiber chip reinforced concrete shells are discussed based on the results of the numerical analysis and the experiment.
\end{abstract}

Keywords : retrofit, carbon fiber sheet, carbon fiber chip, concrete shell 修復，炭素繊維シート，炭素短纎維，コンクリートシェル

\section{1. 序論}

コンクリートシェル構造は、柱の無い大空間を覆う軽快な構造 形式 ${ }^{1,2)}$ として、これまで多くの建築物が建設され ${ }^{3)}$ 様々な施設と して活用されてきた。鉄筋コンクリートシェル構造の耐力を評価す る試みは、座屈耐力に基づく方法 ${ }^{4)}$ 、理論解に基づく方法 ${ }^{5}$ 、数值 解に基づく方法 ${ }^{6,7)}$ など多くの試みがなされてきたが、鉄筋とコン クリートの複合材料から構成されていることから材料学的にも複雑 なため、幾多の実験的研究に基づく検証 ${ }^{8,9)}$ がなされてきた。近年、 コンクリートの補強材料として、新素材による補強方法に関する研 究が報告されており、Domingo.A らによる鋼繊維補強コンクリート 造シェル ${ }^{10)}$ 、筆者らの炭素短繊維補強コンクリート造シェル ${ }^{11)}$ 、更 に炭素繊維シートを貼り付けた補強方法 ${ }^{12)}$ などの報告が行われて いる。

コンクリートシェル構造は、従来の優れた集客力を有する空間構 造としての役割に加えて、今後は高い耐荷能力を生かして、自然災 害時の避難施設や防災拠点等の公共性の高い建築物としての位置付 けが期待できる。しかし、地震や台風等の自然災害抢よび経年変化 により、コンクリートの剥落、ひび割れ等により部分的な損傷がコ
ンクリートシェル構造に発生した場合、構造物本来の耐力が損なわ れて大惨事を招く危険性は慎重に回避されなければならない。その ため、損傷を受けたシェルおよびこれに対して修復を施したシェル の耐力を適切に評価する問題は、今後の重要な課題であるが、これ に関する報告は、殆どなされていない。

一般に鉄筋コンクリート造シェルの施工において、複雑に変化す るシェルの曲率に対応させた配筋作業が要求される。一方、炭素短 繊維補強コンクリート造シェルでは、この複雑な配筋作業および鉄 筋による異方性を回避し、耐候性に優れ、より同質性が高くひび割 れ抑制効果が期待できるシェル構造を実現することが可能となる。 しかし、鉄筋補強を行わないため、最大耐力経過後の勒性が小さく 脆性的な破壊メカニズムが懸念される。従って、炭素短繊維補強コ ンクリート造シェルの設計においては、安全率を適切に考慮した弾 性設計が最適であると考えられる。このような状況を考慮して、著

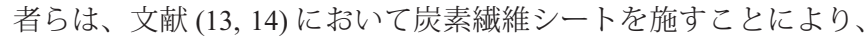
炭素短纎維補強コンクリート造シェルの弾性域および最大耐力を増 大させ、安全性の高い破壊メカニズムの形成に有効であることを示 した。以上を踏まえて、本研究に扔いては、炭素繊維シート補強を $*$ 東海大学大学院総合理工学研究科総合理工学専攻
大学院生 $\cdot$ 修士 $($ 工学 $)$

** 東海大学工学部建築学科 教授. 工博
Graduate Student, Course of Science and Technology, Course in Architectural and Civil Engineering, Tokai Univ., M. Eng.

Prof., Department of Architectural and Building Engineering, Faculty of Engineering, Tokai Univ., Dr. Eng. 
含めて、修復を施したコンクリートシェル構造に焦点を当て、実験 的および数值解析的にシェル耐力を究明する。

本研究における修復は、損傷部の除去、除去後の断面欠損部への 充填およびシート補強を含めて、異なる 3 種の修復に着目し、シェ ル耐力の改善効果を検討する。設定した修復方法は、修復 P(Precut Retrofit)、修復 F(Filler Retrofit) および修復 S(Sheeting Retrofit) である。 修復 P は、損傷部の応力集中を避けるために損傷部の境界に隣接し た領域を円滑に除去して仕上げる方法として定義する。修復 F は、 上記の修復 P を適用した後に、無収縮モルタルを当該領域に充填し て仕上げる方法として定義する。修復 S は、修復 $\mathrm{F}$ を適用した後に、 シェル両面を炭素繊維シートで覆って仕上げる方法として定義す る。コンクリート造の表記として、FC造(炭素短繊維補強コンクリー 卜造)、FC-S 造 (炭素短繊維補強に炭素繊維シート補強を同時に施 した複合炭素繊維補強コンクリート造 ) を定義した。

なお、本研究では、接着剤充填による補修可能なへアークラック が生じた場合および損傷領域が大きく補修困難な場合等の修復を除 外した。従って、局部的な損傷領域に限定した場合を対象とし、修 復がシェルに及ぼす耐力改善効果を明らかにするための基礎的研究 として、屋根型円筒款の端部に局部的損傷が発生した場合を 1 例と して取り上げる。

1 点集中荷重を受ける小型供試体による載荷実験およびこれと対 応する非線形数值解析に基づき、修復がシェルに及ぼす耐力改善効 果を明らかにする。

\section{2. 実験の概要}

修復がシェルに及ぼす耐力改善効果を究明するため静的載荷実験 を行った。このため、14 体の小型実験供試体を作製した。載荷荷 重は、シェル面中央部への 1 点集中荷重とした。なお、載荷実験は、 コンクリート造シェルが最大耐力を経験した状態で終了とした。そ の理由は、最大耐力時のひび割れ形態を出来る限り正確に温存する ためである。更に、炭素短繊維補強コンクリート造シェルにおいて、 文献 (14) により最大耐力経過後、分離破壊等の勒性の少ない崩落的 な破壞を生じやすい傾向が示されており、本研究の最大耐力経過後 の速やかな除荷は、この時点のひび割れ形態の再現が困難となる危 険性を回避する意図に基づくものである。実験に用いた供試体は、 Fig.1(a) に示したように、水平投影面において、一辺 $500 \mathrm{~mm}$ の正方 形とし、設計シェル板厚 $\mathrm{T}_{0}(=8 \mathrm{~mm}) 、$ ライズ・スパン比を $1 / 5$ と設定 した。なお、これは曲率半径 $362.5 \mathrm{~mm}$ 、全開角 $87.1^{\circ}$ となる。支持 方法は、シェル端部を 4 点支持とし、4つのコンクリート製の支承 上に均しモルタルを敷き、その上に供試体を設置した。

炭素繊維シート (Table 1(a) : シート板厚 $\mathrm{t}_{0}=0.19 \mathrm{~mm}$ ) は、シェル上 下各面の全領域に渡って貼り付けとした。この繊維シート補強領域 は、既往の研究から ${ }^{14)}$ シェル両面の全領域を補強したものが最も 効果的であるという知見を得ているためである。コンクリートの調 合は、セメント対骨材 (最大粒径 $1.2 \mathrm{~mm}$ ) の重量比を 1 対 1.5、水セ メント比を $47 \%$ とし、炭素短繊維 (Table 1(b)) をセメント重量に対 して、 $2.0 \%$ 混入した。コンクリートの調合は、より精度の高い混 練を目的としてオムニミキサーを用い、材料の均質性の改善を図っ た。

修復部の詳細寸法は、Fig.1(b) に示した通り、幅 $4 \mathrm{~mm}$ および
$20 \mathrm{~mm}$ とした。修復長さは、水平投影面において、X方向もしくは Y 方向のどちらか一方に、それぞれ $62.5 \mathrm{~mm}$ と設定した。この修復 部は 1 つの供試体において 2 箇所設け水平投影面においてそれぞれ のスパン中央を通る線上の両端に配置した。なお、Fig.1には、X 方向の修復を施した供試体を示している。修復部の断面欠損の製作 方法は、コンクリート打設前にスタイロフォームをアクリル製の両 面型枠へ設置し、型枠脱型時にスタイロフォームを除去する方法を 適用した。修復 P における修復状態は、上記の断面欠損の製作方法 のみを適用したものである。修復 F による供試体は、修復 P によ る断面欠損部にセメント系無収縮モルタル $\left(\mathrm{E}=29.5 \mathrm{GPa}, \mathrm{F}_{\mathrm{c}}=67.5\right.$ $\mathrm{MPa}, \mathrm{F}_{\mathrm{t}}=3.82 \mathrm{MPa}$ ) を充填し、作製した。修復 $\mathrm{S}$ による供試体は、 修復 Fによる修復後、エポキシ系樹脂を塗布して炭素繊維シートを

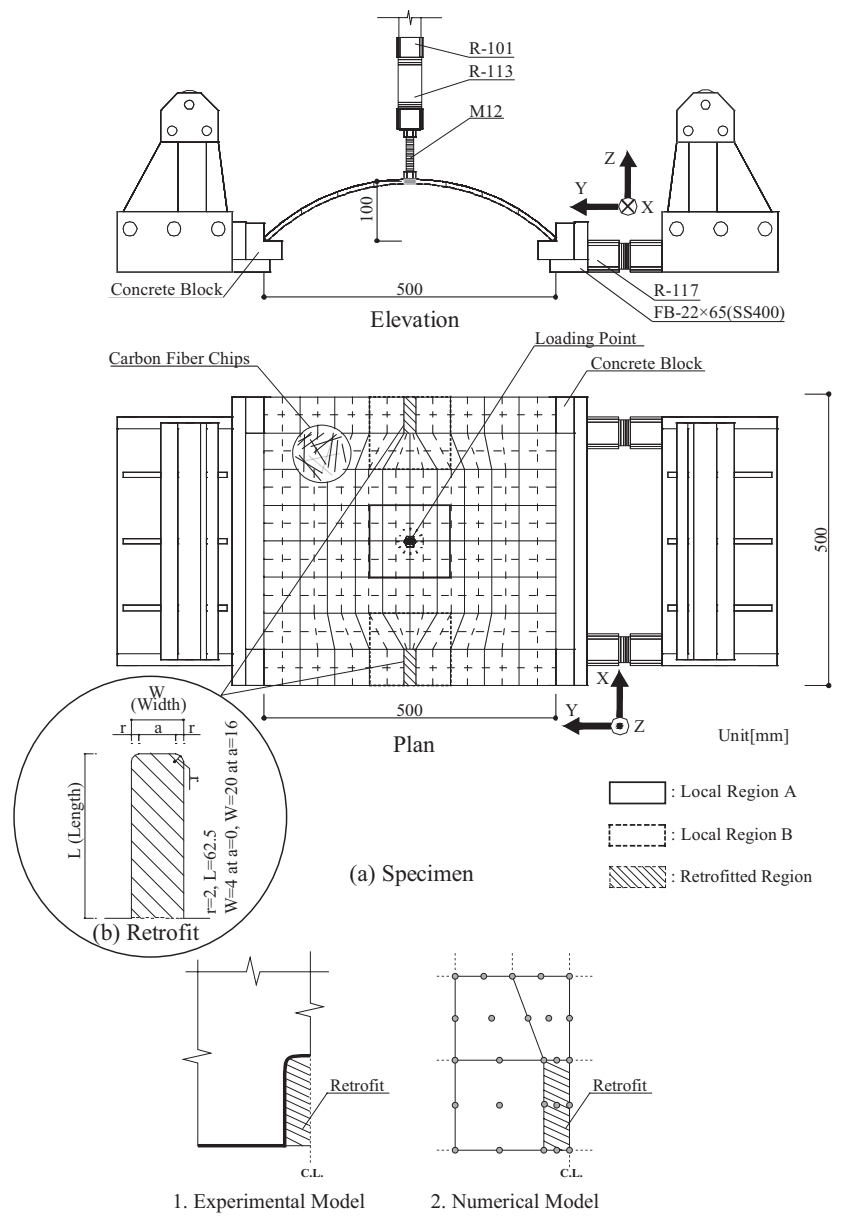

(c) Mesh Subdivision Adjacent to the Retrofit Fig. 1 Shell Model

Table 1(a) Material Property of Carbon Fiber Sheets

\begin{tabular}{c|c|c|c|c|c}
\hline Type & $\begin{array}{c}\text { Fiber } \\
\text { Diameter } \\
{[\mu \mathrm{m}]}\end{array}$ & $\begin{array}{c}\text { Tensile } \\
\text { Strength } \\
{[\mathrm{GPa}]}\end{array}$ & $\begin{array}{c}\text { Modulus } \\
\text { of } \\
\text { Tensile } \\
\text { Elasticity } \\
{[\mathrm{GPa}]}\end{array}$ & $\begin{array}{c}\text { Elongation } \\
{[\%]}\end{array}$ & $\begin{array}{c}\text { Density } \\
{\left[\mathrm{N} / \mathrm{mm}^{3}\right]}\end{array}$ \\
\hline TR3110MS & 17.0 & 1.12 & 71.6 & 1.5 & $1.03 \times 10^{-5}$ \\
\hline
\end{tabular}

Table 1(b) Material Property of Carbon Fiber Chips

\begin{tabular}{c|c|c|c|c|c}
\hline Type & $\begin{array}{c}\text { Fiber } \\
\text { Diameter } \\
{[\mu \mathrm{m}]}\end{array}$ & $\begin{array}{c}\text { Tensile } \\
\text { Strength } \\
{[\mathrm{GPa}]}\end{array}$ & $\begin{array}{c}\text { Modulus } \\
\text { of } \\
\text { Tensile } \\
\text { Elasticity } \\
{[\mathrm{GPa}]}\end{array}$ & $\begin{array}{c}\text { Fiber } \\
\text { Length } \\
{[\mathrm{mm}]}\end{array}$ & $\begin{array}{c}\text { Density } \\
{\left[\mathrm{N} / \mathrm{mm}^{3}\right]}\end{array}$ \\
\hline $\mathrm{K} 661$ & 17.0 & 1.77 & 180.0 & 18.0 & $1.90 \times 10^{-5}$ \\
\hline
\end{tabular}


両面に貼り付け作製した。

Table 2 には各供試体名の文字表記構成、コンクリートの材料定数、 施工シェル板厚の平均值および標準偏差 (全面領域と限定領域) を 示す。ここで、全面領域 (Global Region) は供試体水平投影面におけ るシェル全面を示し、限定領域は以下の 3 領域を設定した。

(1)限定領域 $\mathrm{A}($ Local Region A)：載荷点を中心とした全面領域の 1/16であり Fig.1(a)の太い実線で示す領域である。

(2)限定領域 B(Local Region B)：X方向の修復部 (同図の斜線部 ) を含む全面領域の $1 / 16$ であり、同図の太い点線で示した領域 である。

(3)限定領域 C(Local Region C)：Y 方向の修復部を含む全面領域の $1 / 16$ である。なお、当該領域は上記の限定領域 $\mathrm{B}$ を載荷点に 関して 90 度回転させた位置にある。

Table 2 に扔いて、全面板厚 $\mathrm{T}_{\mathrm{aG}}$ (Global Average) は、シェル全面の 施工板厚実測值の平均值を示し、限定板厚 $\mathrm{T}_{\mathrm{aA}}, \mathrm{T}_{\mathrm{aB}}, \mathrm{T}_{\mathrm{aC}}$ (Local Average A, B , C) は対応する限定領域 A, B, C(Local Region A, B, C) における 施工板厚の実測值の平均值を示す。標準偏差 (STDEV) は上記の全 面領域と $\mathrm{A}, \mathrm{B}, \mathrm{C}$ の各限定領域に対して $\mathrm{T}_{\mathrm{sG}}, \mathrm{T}_{\mathrm{sA}}, \mathrm{T}_{\mathrm{sB}}, \mathrm{T}_{\mathrm{sC}}$ で示した。こ こで、シート補強無しの健全な供試体 FPnn は FC 造、シート補強 有りの健全な供試体 FSnn は FC-S 造に相当する。

\section{3. 数值解析の概要}

本研究において、FC 造および FC-S 造円筒款の耐力を理論的に検 討するため、材料および幾何学的非線形有限要素解析を行った。使 用した要素は、3 次元退化厚肉シェル要素である。変位関数として 双 2 次ラグランジェ型 (Lagrange) を採用し、板厚方向に積層分割を 行った 9 節点アイソパラメトリック系要素を適用した。要素分割は、 $\mathrm{X}$ 方向 10 分割および $\mathrm{Y}$ 方向 10 分割とし、板厚を 10 層に分割した。 なお、修復 $\mathrm{F} ・ \mathrm{~S}$ の修復部分におけるコンクリートのモデル化は、 炭素短繊維補強コンクリートは適用せず「2. 実験の概要」内で示し た無収縮モルタルのみを使用し、シェル板厚を 10 分割とした。こ の修復部のモデル化において、実験供試体および数值解析の要素分 割を Fig.1(c)に示す。コンクリートおよび炭素繊維シートの材料構
成則は Fig.2 に示した通りである。同図 (a) にコンクリートの応力度 - ひずみ度関係を示し、同図 (b) にコンクリートの降伏曲面を示す。 同図 (c) に、炭素繊維シートの応力度 - ひずみ度関係を示した。

コンクリートの引張挙動は、分布ひび割れ型モデルを採用し、引 張剛性は文献 (13) と同様に、コンクリートの引張強度 $\mathrm{F}_{\mathrm{t}}$ の 8 割の 応力度と引張ひずみ度の関係を線形に仮定した。次に、炭素短繊維 補強コンクリートにおける圧縮場の材料構成則を検討するため、炭 素短繊維無混入コンクリートと比較して Fig.3 に応力度 - ひずみ度 曲線を示す。同図の実線 A は、本実験の材料試験において、代表 的な 5 本のテストピースを選定し、その圧縮強度試験の結果に基づ き、平均值を示した。比較のため、文献 (15) の鉄筋コンクリート 造シェルで使用した炭素短繊維無混入コンクリート材料の場合を 点線 B で示した。ここで、上記の実線 $\mathrm{A}$ と点線 $\mathrm{B}$ は、同一の水セ メント比に統一している。点線 B で示した供試体は、粗骨材 (粒 径 $1.2 \mathrm{~mm}$ を超え $2.5 \mathrm{~mm}$ 以下) ・細骨材 (粒径 $1.2 \mathrm{~mm}$ 以下) ・ セメン トの重量比は 1 対 1 対 1 であり、代表的なテストピース 6 本の平均 值である。同図は、無次元化表示であり、縦軸は最大圧縮応力度比 $\sigma^{\prime}\left(=\sigma / \sigma_{\max }, \sigma\right.$ : 圧縮応力度, $\sigma_{\text {max }}$ : 最大圧縮応力度 $)$ であり、
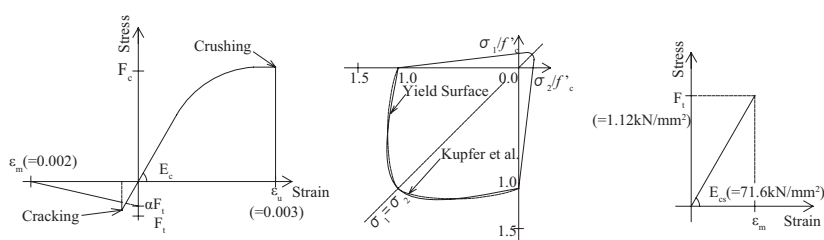

(a) Stress vs. Strain Curve of FC (b)Two-Dimensional Stress Space (c) Stress vs. Strain Curve of Represenation of the

Fig. 2 Constitutive Model

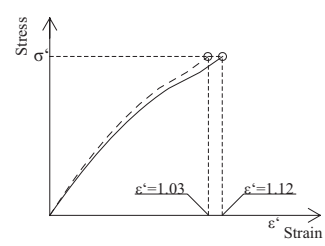

A: Carbon Fiber Chip Reinforced Concrete

Note) $\sigma^{c}\left(=\sigma / \sigma_{\max }\right), \sigma_{\max }$ $\varepsilon^{\prime}\left(=\varepsilon / \varepsilon_{\mathrm{u}}\right), \varepsilon_{\mathrm{u}}=0.003$

Fig. 3 Stress vs. Strain Curve of Concrete

Table 2 Material Property of Concrete and Shell Thickness

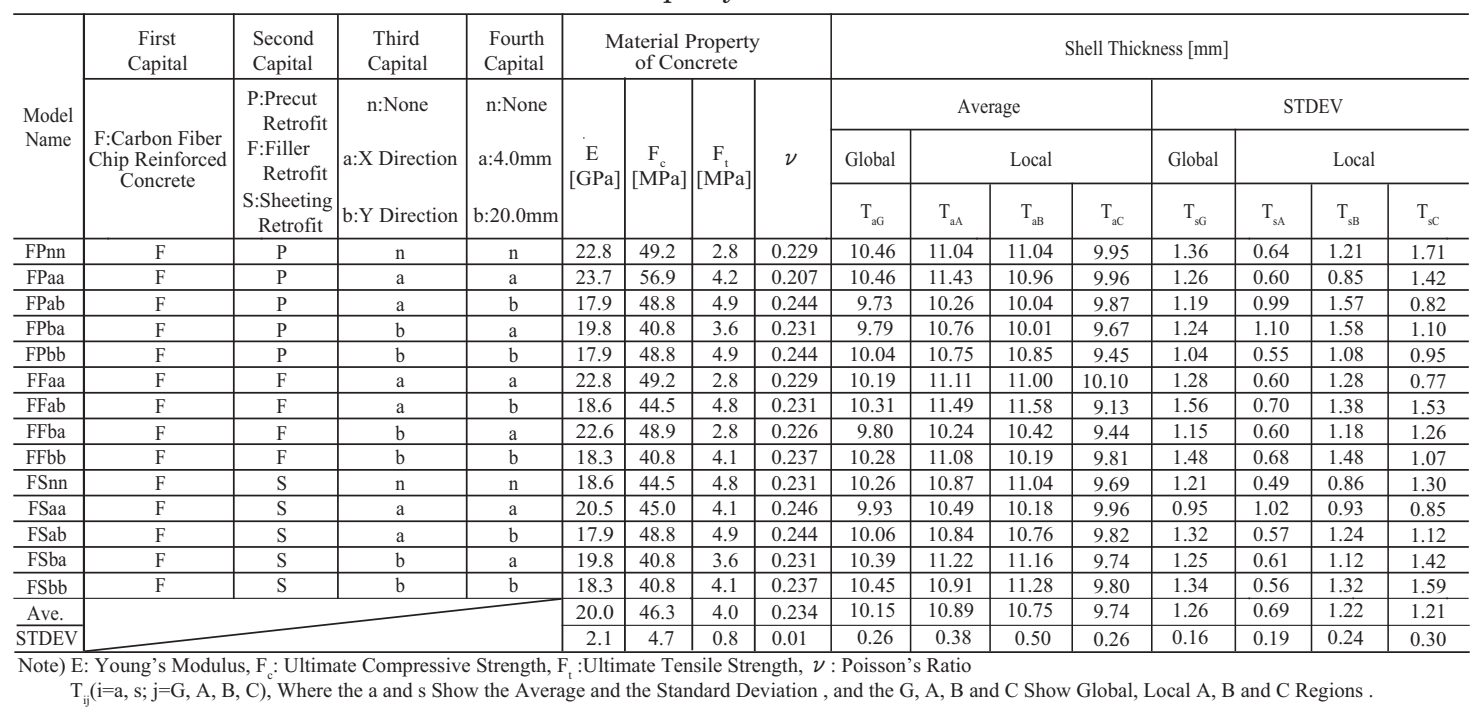


横軸は最大圧縮ひずみ度比 $\varepsilon^{\prime}\left(=\varepsilon / \varepsilon_{u}, \varepsilon\right.$ : 圧縮ひずみ度, $\varepsilon_{u}$ : 終局圧縮ひずみ度 0.003$)$ である。 $\sigma_{\text {max }}$ は、実線 $\mathrm{A}$ で $43.0 \mathrm{kN} / \mathrm{mm}^{2}$, 点線 B で $44.2 \mathrm{kN} / \mathrm{mm}^{2}$ であり、実線 A と点線 B は比較的類似してい る。秋浜らの既往の文献において ${ }^{10}$ 、混入量 $2 \%$ 場合は、䛊差 $10 \%$ の範囲で終局圧縮ひずみ度は 0.003 で適切であることが示されてい る。以上より、本研究では、鉄筋コンクリート造と同様に終局圧縮 ひずみ度を 0.003 とし、この值を超えた場合、圧縮破壊と判定した。 繊維補強コンクリート部材に曲げが作用した場合は、通常の鉄筋 コンクリートの場合と異なり、一般に引張場に比べて圧縮場が部材 の耐力に与える影響は少ないことが指摘されている ${ }^{17}$ 。即ち、繊維 補強コンクリートの場合は、鉄筋が無いことにより引張側の耐力が 低いため、圧縮側が降伏する以前に終局状態を迎えることが指摘さ れており、圧縮側への影響が小さい。一般に、繊維補強コンクリー トの場合、压縮ひずみ度は、上記の 0.003 に到達する以前の 0.002 以下に収まることが報告されている ${ }^{17)}$ 。従って、繊維補強コンクリー ト材料においては、圧縮側の応力場に対応して ${ }^{13,14,18)}$ 、鉄筋コンク リート材料に有効な構成則の適用性が高いと考えられる。本研究で は Fig.2(b) に示した通り、クーパーの実験結果を考慮した構成則を 適用した ${ }^{19,20)}$ 。

炭素纎維シートの数值モデル化においては、文献 (13) に基づき、 $\mathrm{X}$ と Y 方向で剛性が分離する直剛性モデルを採用した。計算は応力 制御により、最大耐力までの計算を行った。なお、各実験供試体の 名称と対応する数值解の名称は同一名とする。

数值解は、施工板厚および材料特性の変化を考慮して 3 種類を設 定した。これらは、数值解 S (Standard Solution)、数值解 D (Discrete Solution) および数值解 A (Average Solution) である。数值解 S は、 全ての供試体の材料定数を一定值 $\left(\mathrm{E}=20 \mathrm{GPa}, \mathrm{F}_{\mathrm{c}}=40 \mathrm{MPa}, \mathrm{F}_{\mathrm{t}}=4\right.$ $\mathrm{MPa}, v=0.20)$ に設定し、板厚を設計シェル板厚 $\mathrm{T}_{0}$ に設定したもの である。数值解 D は、供試体毎の 441 点からなる施工板厚実測值 を有限要素の各節点に反映させた板厚および各供試体と対応した材 料試験結果に基づく材料諸元を設定したものである。数值解 $\mathrm{A}$ は、 上記の施工板厚実測值の平均を有限要素の各節点に設定した板厚お よび各供試体と対応した材料試験結果に基づく材料諸元を設定した ものである。

実験と解析の支持条件の対応を検討するため、文献 (14) と同様に 4 種の数值解支持条件を設定し、Fig.4 に示した。同図の記号 EXP は実験、 $\mathrm{N}_{0}, \mathrm{~N}_{1}, \mathrm{~N}_{2}, \mathrm{~N}_{3}$ は数值解析を示す。記号 $\mathrm{N}_{0}$ は、支承部全長に 渡るピン支持を示す。記号 $\mathrm{N}_{1}$ から $\mathrm{N}_{3}$ は、それぞれの支承部の外端、 中央および内端でのピン支持を示す。ここで、実験での繊維シート 補強無しの健全な供試体 (FPnn) は、数值解 D との良い対応が確認 されており ${ }^{13,14)}$ 、数值解 D の FPnn を用いた解析結果より荷重変位 曲線を Fig.5 に示した。同図の EXP は、 $\mathrm{N}_{3}$ と最も良い対応を示し ているため、本解析は、 $\mathrm{N}_{3}$ 状態の支持条件を用いて解析を行う。

\section{4. 載荷実験および数值解析の結果}

\section{1 数值解 $\mathrm{S}$ に基づく耐力補正}

既往の研究 ${ }^{13,14,15)}$ より、実験供試体の耐力は施工シェル板厚の変 動によって大きく左右されることが示されている。本研究ではコン クリートの打設に㨟いて両面型枠を使用しており板厚変動を相当程 度に抑制した施工を施しているが、若干の板厚変動は確認されてい
る。したがって、板厚と材料諸元を統一した数值解 $\mathrm{S}$ に基づき施工 板厚の変動を考慮して、実験の耐力を確認する。その結果をまとめ て Table 3(a-c) に示す。ここで、全供試体を母集団 A、X 方向の修 復を含む供試体を母集団 $\mathrm{B} 、 \mathrm{Y}$ 方向の修復を含む供試体を母集団 $\mathrm{C}$ と分類する。まず、全面板厚比をシェル全面領域の実測平均值の板 厚比と定義し、FPnn の実験供試体の全面領域での施工板厚に対す る各供試体の全面板厚比を $T_{G A}, T_{G B}, T_{G C}$ で示す。ここで、 $T_{G A}$ は母 集団 $\mathrm{A}$ を、 $T_{G B}$ は母集団 B を、 $T_{G C}$ は母集団 $\mathrm{C}$ をそれぞれ対象とし ている。次に、限定板厚比をシェル限定領域の実測平均值の板厚比 と定義し、FPnn の実験供試体の限定領域 $\mathrm{A}, \mathrm{B}, \mathrm{C}$ での施工板厚に対 する各供試体の限定板厚比をそれぞれ $T_{L A}, T_{L B}, T_{L C}$ で示す。この $T_{L B}$ と $T_{L C}$ は、 $\mathrm{X}$ 方向両端と $\mathrm{Y}$ 方向両端の修復に基づき、それぞれ 修復箇所と対応した領域の平均板厚比である。

同表 (a) は、全面板厚比 $T_{G A}$ および限定板厚比 $T_{L A}$ に基づき、同 表 (b) は、全面板厚比 $T_{G B}$ および限定板厚比 $T_{L B}$ に基づき、同表 (c) は、全面板厚比 $T_{G C}$ および限定板厚比 $T_{L C}$ に基づき、各耐力補正を 示した。ここで、修復 $\mathrm{P} ・ \mathrm{~F} ・ \mathrm{~S}$ が実験と数值解 $\mathrm{S}$ の耐力に与える影 響を確認するため、個々の耐力とシート補強無しの健全な供試体に 対応する耐力との比を用いて検討を行う。全面板厚比 $T_{G A}, T_{G B}, T_{G C}$ の補正と対応して、FPnnの実験值に対する各実験の耐力比を $E_{\boldsymbol{\theta} A}$, $E_{0 B}, E_{O C}$ で示し、FPnn の数值解に対する各数值解の耐力比を $S_{\theta A}$, $S_{O B}, S_{O C}$ で示す。FPnn の実験值および数值解における最大耐力をそ れぞれ $\mathrm{P}_{0 \mathrm{e}}$ および $\mathrm{P}_{0 \mathrm{~s}}$ で表示すると、 $1.66 \mathrm{kN}\left(=\mathrm{P}_{0 \mathrm{e}}\right)$ および $1.18 \mathrm{kN}(=$ $\left.\mathrm{P}_{0 \mathrm{~s}}\right)$ を得た。領域毎の耐力整合比を、上述の $S_{0 A}, S_{0 B}, S_{0 C}$ に対する $E_{0 A}, E_{0 B}, E_{0 C}$ の比率として、それぞれ $E_{A}, E_{B}, E_{C}$ と定義する。上記 の板厚比の補正を適用した実験耐力比の線形・2 次・3 次補正を求 め、シェル全面領域に対する整合比 $E_{G A 1} \cdot E_{G A 2} \cdot E_{G A 3}, E_{G B 1} \cdot E_{G B 2} \cdot$ $E_{G B 3}, E_{G C 1} \cdot E_{G C 2} \cdot E_{G C 3}$ を求めた。同様に、限定領域 $\mathrm{A} \cdot \mathrm{B} \cdot \mathrm{C}$ に対 する整合比 $E_{L A 1} \cdot E_{L A 2} \cdot E_{L A 3}, E_{L B 1} \cdot E_{L B 2} \cdot E_{L B 3}, E_{L C 1} \cdot E_{L C 2} \cdot E_{L C 3}$ をそれぞれ求めた。以上を縓めて各整合比を次式より求める。

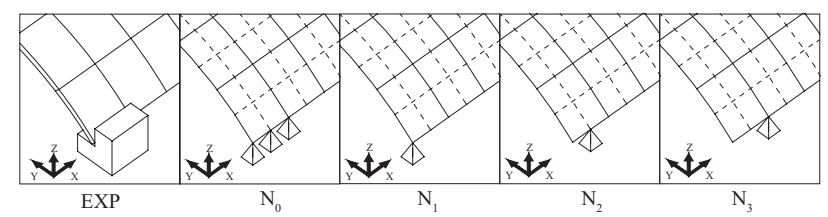

Fig. 4 Support Condition

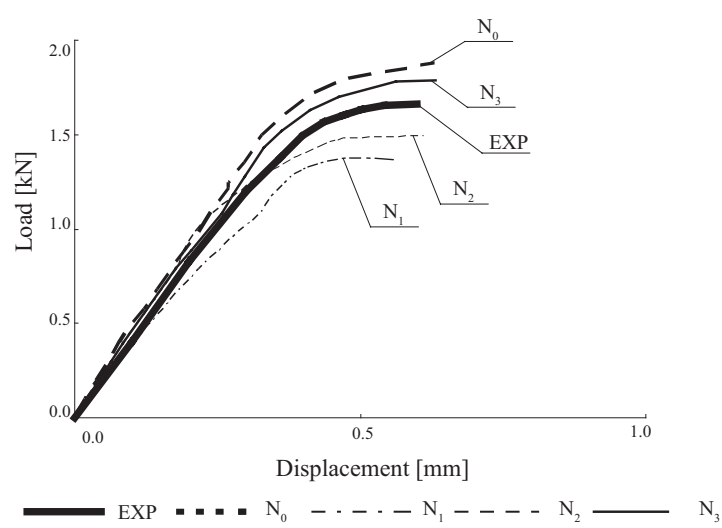

Fig. 5 Load vs. Displacement Curves 
Table 3(a) Strength Ratio Adjusted by Shell Thickness for Region A

\begin{tabular}{c|c|c|c|c|c|c|c|c|c|c|c}
\hline Strength & $E_{0 A}$ & $S_{0 A}$ & $T_{G A}$ & $T_{L A}$ & $E_{A}$ & $E_{G A I}$ & $E_{L A 1}$ & $E_{G A 2}$ & $E_{L A 2}$ & $E_{G A 3}$ & $E_{L A 3}$ \\
\hline FPaa/FPnn & 0.81 & 0.88 & 1.00 & 1.04 & 0.92 & 0.92 & 0.89 & 0.92 & 0.86 & 0.92 & 0.83 \\
\hline FPab/FPnn & 0.90 & 0.91 & 0.93 & 0.93 & 0.99 & 1.06 & 1.06 & 1.14 & 1.15 & 1.23 & 1.23 \\
\hline FPba/FPnn & 0.81 & 0.93 & 0.94 & 0.97 & 0.88 & 0.94 & 0.90 & 1.00 & 0.92 & 1.07 & 0.95 \\
\hline FPbb/FPnn & 0.91 & 0.96 & 0.96 & 0.97 & 0.95 & 0.99 & 0.97 & 1.03 & 1.00 & 1.07 & 1.03 \\
\hline FFaa/FPnn & 0.91 & 0.92 & 0.97 & 1.01 & 0.99 & 1.02 & 0.98 & 1.04 & 0.98 & 1.07 & 0.97 \\
\hline FFab/FPnn & 1.02 & 0.95 & 0.99 & 1.04 & 1.08 & 1.09 & 1.03 & 1.11 & 0.99 & 1.12 & 0.95 \\
\hline FFba/FPnn & 0.86 & 0.97 & 0.94 & 0.93 & 0.89 & 0.95 & 0.96 & 1.01 & 1.03 & 1.08 & 1.11 \\
\hline FFbb/FPnn & 1.03 & 0.99 & 0.98 & 1.00 & 1.05 & 1.06 & 1.04 & 1.08 & 1.04 & 1.10 & 1.03 \\
\hline FSnn/FPnn & 2.42 & 2.68 & 0.98 & 0.98 & 0.90 & 0.92 & 0.92 & 0.94 & 0.93 & 0.96 & 0.95 \\
\hline FSaa/FPnn & 2.39 & 2.55 & 0.95 & 0.95 & 0.94 & 0.99 & 0.99 & 1.04 & 1.04 & 1.10 & 1.09 \\
\hline FSab/FPnn & 2.42 & 2.57 & 0.96 & 0.98 & 0.94 & 0.98 & 0.96 & 1.02 & 0.98 & 1.06 & 1.00 \\
\hline FSba/FPnn & 2.32 & 2.57 & 0.99 & 1.02 & 0.90 & 0.91 & 0.89 & 0.91 & 0.87 & 0.92 & 0.86 \\
\hline FSbb/FPnn & 2.40 & 2.61 & 1.00 & 0.99 & 0.92 & 0.92 & 0.93 & 0.92 & 0.94 & 0.92 & 0.95 \\
\hline Average & - & - & - & - & 0.95 & 0.98 & 0.96 & 1.01 & 0.98 & 1.05 & 1.00 \\
\hline STDEV & - & - & - & - & 0.06 & 0.06 & 0.06 & 0.07 & 0.08 & 0.09 & 0.11 \\
\hline RMS & - & - & - & - & 0.08 & 0.06 & 0.07 & 0.07 & 0.08 & 0.10 & 0.10 \\
\hline
\end{tabular}

Table 3(b) Strength Ratio Adjusted by Shell Thickness for Region B

\begin{tabular}{c|c|c|c|c|c|c|c|c|c|c|c}
\hline Strength & $E_{0 B}$ & $S_{O B}$ & $T_{G B}$ & $T_{L B}$ & $E_{B}$ & $E_{G B 1}$ & $E_{L B 1}$ & $E_{G B 2}$ & $E_{L B 2}$ & $E_{G B 3}$ & $E_{L B 3}$ \\
\hline FPaa/FPnn & 0.81 & 0.88 & 1.00 & 0.99 & 0.92 & 0.92 & 0.93 & 0.92 & 0.93 & 0.92 & 0.94 \\
\hline FPab/FPnn & 0.90 & 0.91 & 0.93 & 0.91 & 0.99 & 1.06 & 1.09 & 1.14 & 1.20 & 1.23 & 1.32 \\
\hline FFaa/FPnn & 0.91 & 0.92 & 0.97 & 1.00 & 0.99 & 1.02 & 0.99 & 1.04 & 1.00 & 1.07 & 1.00 \\
\hline FFab/FPnn & 1.02 & 0.95 & 0.99 & 1.05 & 1.08 & 1.09 & 1.03 & 1.11 & 0.98 & 1.12 & 0.93 \\
\hline FSaa/FPnn & 2.39 & 2.55 & 0.95 & 1.00 & 0.94 & 0.99 & 0.94 & 1.04 & 0.94 & 1.10 & 0.94 \\
\hline FSab/FPnn & 2.42 & 2.57 & 0.96 & 0.92 & 0.94 & 0.98 & 1.02 & 1.02 & 1.11 & 1.06 & 1.20 \\
\hline Average & - & - & - & - & 0.98 & 1.01 & 1.00 & 1.05 & 1.02 & 1.08 & 1.05 \\
\hline STDEV & - & - & - & - & 0.06 & 0.06 & 0.06 & 0.08 & 0.10 & 0.10 & 0.16 \\
\hline RMS & - & - & - & - & 0.06 & 0.06 & 0.05 & 0.08 & 0.10 & 0.12 & 0.16 \\
\hline
\end{tabular}

Table 3(c) Strength Ratio Adjusted by Shell Thickness for Region C

\begin{tabular}{c|c|c|c|c|c|c|c|c|c|c|c}
\hline Strength & $E_{O C}$ & $S_{O C}$ & $T_{G C}$ & $T_{L C}$ & $E_{C}$ & $E_{G C 1}$ & $E_{L C l}$ & $E_{G C 2}$ & $E_{L C 2}$ & $E_{G C 3}$ & $E_{L C 3}$ \\
\hline FPba/FPnn & 0.81 & 0.93 & 0.94 & 0.97 & 0.88 & 0.94 & 0.90 & 1.00 & 0.93 & 1.07 & 0.95 \\
\hline FPbb/FPnn & 0.91 & 0.96 & 0.96 & 0.95 & 0.95 & 0.99 & 1.00 & 1.03 & 1.05 & 1.07 & 1.10 \\
\hline FFba/FPnn & 0.86 & 0.97 & 0.94 & 0.95 & 0.89 & 0.95 & 0.93 & 1.01 & 0.98 & 1.08 & 1.04 \\
\hline FFbb/FPnn & 1.03 & 0.99 & 0.98 & 0.99 & 1.05 & 1.06 & 1.06 & 1.08 & 1.07 & 1.10 & 1.09 \\
\hline FSba/FPnn & 2.32 & 2.57 & 0.99 & 0.99 & 0.90 & 0.91 & 0.91 & 0.91 & 0.93 & 0.92 & 0.94 \\
\hline FSbb/FPnn & 2.40 & 2.61 & 1.00 & 0.98 & 0.92 & 0.92 & 0.94 & 0.92 & 0.96 & 0.92 & 0.98 \\
\hline Average & - & - & - & - & 0.93 & 0.96 & 0.96 & 0.99 & 0.99 & 1.03 & 1.02 \\
\hline STDEV & - & - & - & - & 0.06 & 0.06 & 0.06 & 0.06 & 0.06 & 0.08 & 0.07 \\
\hline RMS & - & - & - & - & 0.09 & 0.07 & 0.07 & 0.06 & 0.06 & 0.08 & 0.06 \\
\hline
\end{tabular}

$$
\begin{aligned}
& E_{i}=E_{0 i} / S_{0 i},(\mathrm{i}=\mathrm{A}, \mathrm{B}, \mathrm{C}) \\
& E_{G i m}=E_{i} /\left(T_{G i}\right)^{\mathrm{m}},(\mathrm{i}=\mathrm{A}, \mathrm{B}, \mathrm{C}, \mathrm{m}=1,2,3) \\
& E_{L i m}=E_{i} /\left(T_{L i}\right)^{\mathrm{m}},(\mathrm{i}=\mathrm{A}, \mathrm{B}, \mathrm{C}, \mathrm{m}=1,2,3)
\end{aligned}
$$

耐力補正効果を評価するために各母集団の平均值 (Average)、標 準偏差 $(\mathrm{STDEV}) 、$ 二乗平均平方根 $(\mathrm{RMS})$ を同表に示した。実験耐 力比と数值解耐力比の整合性を評価するためには基準值 1.0 からの 偏差距離を示す RMS が効果的であると考えられる。

Table 3(a) より、RMS で比較すると耐力補正を行わない $E_{A}$ の 0.08 と比較して、 $E_{G A I}$ の 0.06 が最も 0.00 に近く良い結果を示している。 これは、全面板厚比による 1 次補正、即ちシェルの面内力に対する 補正である。

Table 3(b) より RMS で比較すると耐力補正を行わない $E_{B}$ の 0.06 と比較して、 $E_{L B 1}$ の 0.05 が最も 0.00 に近く良い結果を示している。 これらは X方向の修復領域に関して、限定領域 B による 1 次補正、 即ちシェルの面内力に対する補正である。限定領域 B は、シェル両 端のアーチ効果による耐力を直接補正するものである。

Table 3(c) より RMS で比較すると耐力補正を行わない $E_{C}$ の 0.09 と比較して、 $E_{G C 2}, E_{L C 2}, E_{L C 3}$ の 0.06 が最も 0.00 に近く良い結果を示 している。ここで、上記の 3 者の平均值および標準偏差を比較する と、 $E_{G C 2}$ および $E_{L C 2}$ の平均值 0.99 および標準偏差 0.06 が最適であ る。これらはY 方向の修復領域に関して、全面領域および限定領域 $\mathrm{C}$ による2 次補正、即ちシェルの面外力に対する補正である。シェ ル裾部両端の $\mathrm{X}$ 方向の曲げ抵抗を直接補正するものである。

ここで、限定領域 A, B C C 最大主応力度を比較するため、修復 $\mathrm{P}$ による FPab および $\mathrm{FPbb}$ を取り上げ、単位集中荷重 $1 \mathrm{kN}$ 載荷時
の応力度を弾性応力解析により求めた。シェル面全領域の最大応力 度 $\sigma_{0}\left(\mathrm{FPab}\right.$ で $21.7 \mathrm{~N} / \mathrm{mm}^{2}, \mathrm{FPb}$ で 21.5N/ $\left.\mathrm{mm}^{2}\right)$ に対する応力度比 $R_{s}\left(=\sigma / \sigma_{0}, \sigma\right.$ : 主応力度 $)$ を Fig.6に示した。この $\sigma_{0}$ は、いずれ も限定領域 $\mathrm{A}$ の載荷点直下のシェル下面における值となる。同図 に示した通り、限定領域 $\mathrm{B} て ゙ ~ 0.49\left(=R_{s}\right)$ および限定領域 C で 0.02(= $\left.R_{s}\right)$ を得た。従って、今回対象とした供試体では載荷点直下の限定 領域 $\mathrm{A}$ および全面領域の耐力補正が有効であると考えられる。以上 を考慮して、Table 3(a-c) に対する考察をまとめると、Table 3(a) で 示した全面板厚比 $T_{G A}$ による 1 次補正 $E_{G A I}$ が最も有効であると考 えられる。

次に、文献 (21) の炭素短繊維混入量 4\% と本研究の混入量 $2 \%$ に おいて、シート補強無しの健全な供試体の実験耐力は、同文献の $2.35 \mathrm{kN}$ および前述の $\mathrm{P}_{0 \mathrm{e}}$ が示された。これにより、 $29 \%$ の耐力低下 が確認された。

\section{2 数值解Sにおいて修復が耐力に及ぼす影響}

数值解 $\mathrm{S}$ の耐力から 3 種の修復効果を検討する。Table 3(a) より 修復 P に関して、耐力は $4 \%$ 減 (FPbb) から $12 \%$ 減 (FPaa) が示され た。修復幅の相違によって耐力が異なる理由は、修復幅の狭い領域 に拈いて応力集中が生じ、より大きなシェル耐力の低下を招いたと 考えられる。修復 F に関して、耐力は 1\%減 (FFbb) から $8 \%$ 減 (FFaa) が示され、修復 P の場合と比べて耐力の減少が抑制され、修復 F に よる耐力の改善効果が示された。この修復 $\mathrm{F}$ を施した供試体の耐 力が FPnn より小さい理由は、修復部における無収縮モルタルの材 料特性の值（コンクリート引張剛性パラメーター $\alpha$ 、コンクリート の引張強度 $\mathrm{F}_{\mathrm{t}}$ ) が、炭素短繊維補強コンクリート造の対応する各值 より小さいことに起因していると考えられる。なお、修復部のモル 


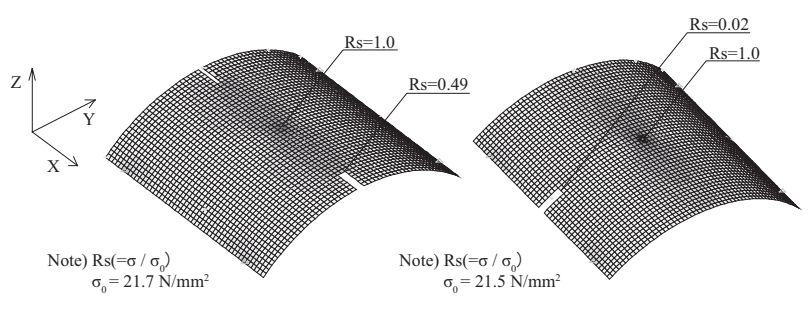

(a) FPab

(b) FPbb

Fig. 6 Major Principal Stress on the Bottom Surface under Point Load $1 \mathrm{kN}$

タルの引張剛性は、炭素短繊維補強が無いため、零が採用されてい る。修復 $\mathrm{S}$ に関して、全ての場合に 2.55 倍以上の耐力増加が示され、 修復 S を施した場合に優れた耐力の改善効果が確認された。

ここで、本研究における設計シェル板厚 $\mathrm{T}_{0}(「 2$. 実験の概要」に 記載したシェル板厚) は、鉄筋コンクリート構造計算基準における 22)、スラブ厚 $80 \mathrm{~mm}$ 、耐震壁厚 $120 \mathrm{~mm}$ を最低断面としていることを 考慮し、実施設計上はシェル板厚として $120 \mathrm{~mm}$ 程度を想定として いる。実大模型におけるシェル板厚と実験供試体の設計シェル板厚 では、シェル板厚とシート板厚の相対比率が異なるため、シェル耐 力に及ぼす効果において相当程度の相違が予測される。従って、シー ト板厚と本研究における設計シェル板厚 $\mathrm{T}_{0}$ との相対比を変化させ てシート補強効果を検討する。シート補強有り FSnn の耐力とシー 卜補強無し FPnnの耐力との比をシート耐力比 $R_{p}\left(=\mathrm{p} / \mathrm{P}_{0 \mathrm{~s}}, \mathrm{p}\right.$ : FSnn に おける数值解 $\mathrm{S}$ の耐力、 $\mathrm{P}_{0 \mathrm{~s}}$ : FPnn における数值解 $\mathrm{S}$ の耐力 ) と定義 し、シート板厚 $\mathrm{t}$ に対するシェル板厚 $\mathrm{T}$ の比をシート板厚比 $R_{t}(=\mathrm{t} / \mathrm{T})$ と定義する。更に、本研究で採用したシート板厚 $\mathrm{t}_{0}(「 2$. 実験の概 要」に記載したシート板厚 ) および設計シェル板厚 $\mathrm{T}_{0}$ の比を実験 シート板厚比 $R_{0}\left(=\mathrm{t}_{0} / \mathrm{T}_{0}\right)$ と定義する。本研究のシェルスパンは、規 模が小さいためシェル板厚をそのまま増大させた場合には、シェル 板厚が薄肉シェルの仮定から逸脱するため、便宜上シェル板厚 $\mathrm{T}$ を $\mathrm{T}_{0}$ に固定してシート板厚 $\mathrm{t}$ を変化させた解析を行い、 $R_{p}$ と $R_{t}$ の関 係を求めて、Fig.7 に示した。同図の横軸は、 $R_{t}$ を対数表示で示し、 図中の点 $\mathrm{A}$ から $\mathrm{D}$ の值は、実験シート板厚比 $R_{0}$ を用いて示した。 同図は、本研究で採用したシート板厚比 $R_{0}($ 点 $\mathrm{A})$ からシート板厚
比 $R_{\theta} / 1000$ (点 $\mathrm{B}$ ) までのシート板厚比の範囲を対象として、 $R_{p}$ と $R_{t}$ の相関関係を示している。同図の横軸 $\left(\log _{10} \mathrm{R}_{\mathrm{t}}\right)$ において、 $\log _{10}\left(\mathrm{R}_{0} /\right.$ 10) および $\log _{10}\left(R_{0} / 100\right)$ と対応した曲線上の点をそれぞれ点 $C$ お よび点 D で示す、点 C では、緩やかな減少傾向を示し、点 D では、 ほぼ一定值を示す。上記の点 $\mathrm{A}$ から点 $\mathrm{D}$ までと対応した $R_{t}$ の值を $R_{t A}$ から $R_{t D}$ で、同様に $R_{p}$ の值を $R_{p A}$ から $R_{p D}$ で示した。点 $\mathrm{A}$ から 点 $\mathrm{D}$ と対応した $R_{p}$ の值は、それぞれ 3.40、1.00、1.29、1.07 となる。 同図において、シート板厚 $\mathrm{t}_{0}$ の場合に、シェル板厚 $\mathrm{T}$ を $120 \mathrm{~mm}$ に 増大するとシート耐力比 $R_{p}$ は $63 \%$ 減 $(=1-1.25 / 3.40)$ となる。

同図より、シート補強を行った場合の耐力は、Felix Candela ${ }^{23)}$ の 宇宙線研究所（鉄筋コンクリート造シェル板厚 $15 \mathrm{~mm}$ ）で 2.6 倍、 Jorg Schlaich ${ }^{24)}$ の Federal Garden Exhibition（ガラス繊維補強コンク リート造シェル板厚 $12 \mathrm{~mm}$ ) で 2.9 倍、シェル板厚 $120 \mathrm{~mm}$ の場合には、 1.2 倍以上が期待できる。なお、実際の繊維補強コンクリート造シエ ルにおいては、従来の鉄筋のかぶり厚が不要であり、より薄肉のシェ ルの設計・施工が期待できる。 $R_{p}$ が 1.5 倍以上で板厚 $48 \mathrm{~mm}$ 以下、 $R_{p}$ が 2.0 倍以上で板厚 $23 \mathrm{~mm}$ 以下が示された。従って、纎維シート 補強により、この板厚以下の場合には、短期荷重の規模を長期荷重 として取り扱うことができる可能性を示した。

\section{3 施工板厚を考慮した数值解による耐力}

実験耐力と数值解 $\mathrm{D}$ および数值解 A による耐力を比較して Fig. 8 に示す。ここで、数值解析の最大耐力 $P_{n u m}$ から実験の最大耐力 $P_{\text {exp }}$ を差し引いた誤差耐力 $P_{d i f}\left(=P_{n u m}-P_{\text {exp }}\right)$ と実験の最大耐力 $P_{\text {exp }}$ との比を最大耐力誤差比 $r_{\text {err }}\left(=P_{\text {dif }} / P_{\text {exp }}\right)$ と定義した。同図より、 FPnn, FPaa, FPab, FPba およびFPbb において、それぞれ数值解 D の 誤差比が、 $0.6 \%$ 増、 $1.5 \%$ 増、 $3.4 \%$ 減、 $2.2 \%$ 減および $2.0 \%$ 減とな り、数值解 $\mathrm{A}$ と比較して実験值との良好な対応が示された。同様に、 FFaa, FFab, FFba およびFFbb においても数值解 D で、それぞれ誤差 比が、 1.3 \%減、 $1.2 \%$ 増、 $2.8 \%$ 増および $2.3 \%$ 増となり、実験值と の良好な対応が示された。修復 P・F では、板厚変動を忠実に再現 した数值解 $\mathrm{D}$ と実験值の良い対応が示されたのに対し、シート補強 有りの FSnn, FSaa, FSab, FSba およびFSbb では、数值解 A において、 誤差比がそれぞれ $4.5 \%$ 増、 $1.0 \%$ 減、 $2.0 \%$ 増、0.8\%減および $1.5 \%$ 減となり、数值解 $\mathrm{A}$ と実験值との良好な対応が示された。これは、

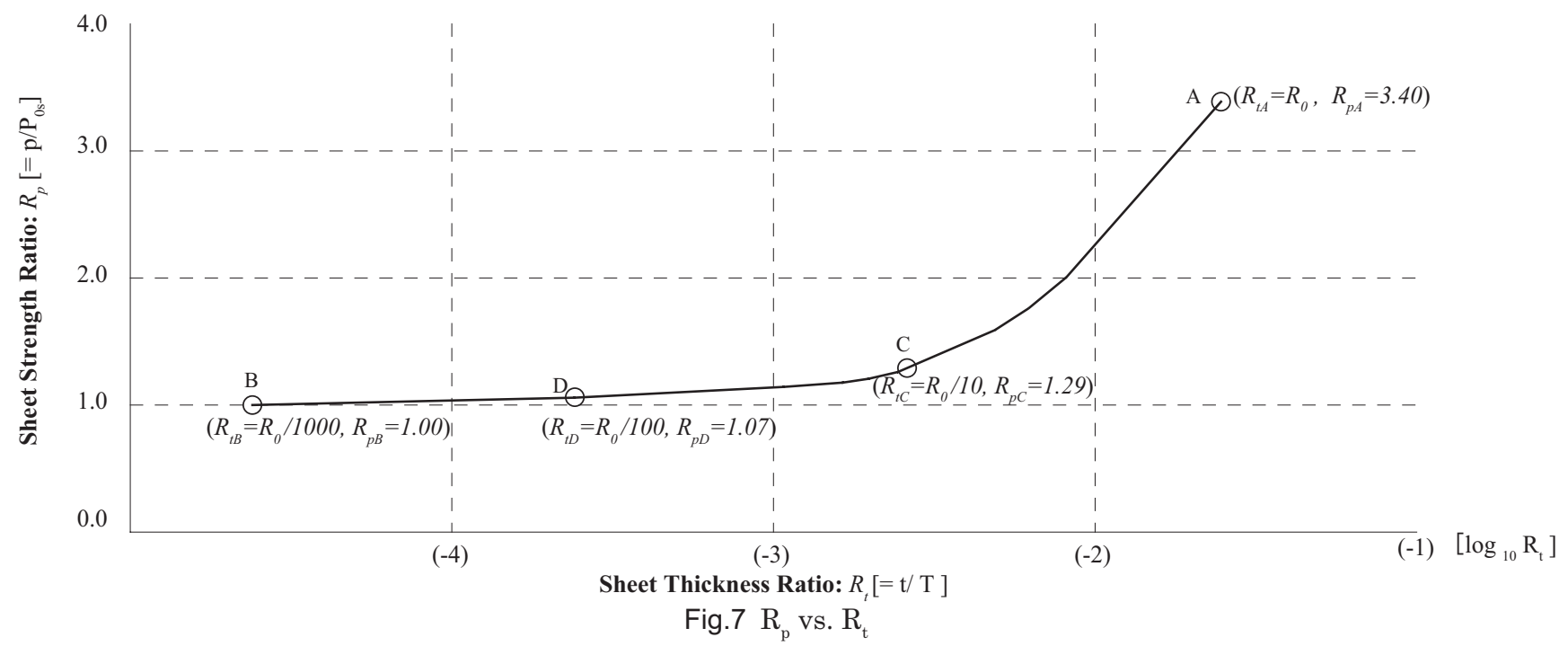


修復 S を施した場合、シート補強により板厚変動の影響が抑制され たことにより、数值解 $\mathrm{A}$ の結果が実験值と良い対応を示したものと 考えられる。

次に、数值解 $\mathrm{D}$ および数值解 $\mathrm{A}$ による各修復方法の効果につ いて検討する。まず、シート補強無しの健全な供試体 FPnn と修復 $\mathrm{P}$ による耐力を比較検討する。Fig.8 より数值解 D において、最大 耐力を比較すると、FPnnの $1.67 \mathrm{kN}$ に対して、FPaa、FPab、FPba 抢よび $\mathrm{FPbb}$ で $18.0 \%$ 減、13.8\% 減、 $21.0 \%$ 減および $11.4 \%$ 減の耐 力が確認された。続いて、修復 P・F による耐力を比較検討する。 FPaaに対して FFaa は $8.8 \%$ 増、FPabに対して FFab は $19.4 \%$ 増、 FPba に対して FFba は $11.4 \%$ 増、FPbb に対して FFbb は $18.2 \%$ 増と なり、それぞれ耐力の増加が確認された。これは、修復領域に充填 した無収縮モルタルによって修復領域での応力集中が抑制されたこ とに起因すると考えられる。これより、修復 F による修復効果が定 量的に明示された。さらに、数值解 $\mathrm{A}$ において、修復 $\mathrm{S}$ を用いた 最大耐力を比較すると、シート補強無しの健全な供試体 FPnn の耐 力に対して、2.4 倍以上の耐力増加が確認された。これより、修復 $\mathrm{S}$ によるシェル耐力の大幅な改善効果が示された。

\section{4 荷重変位曲線}

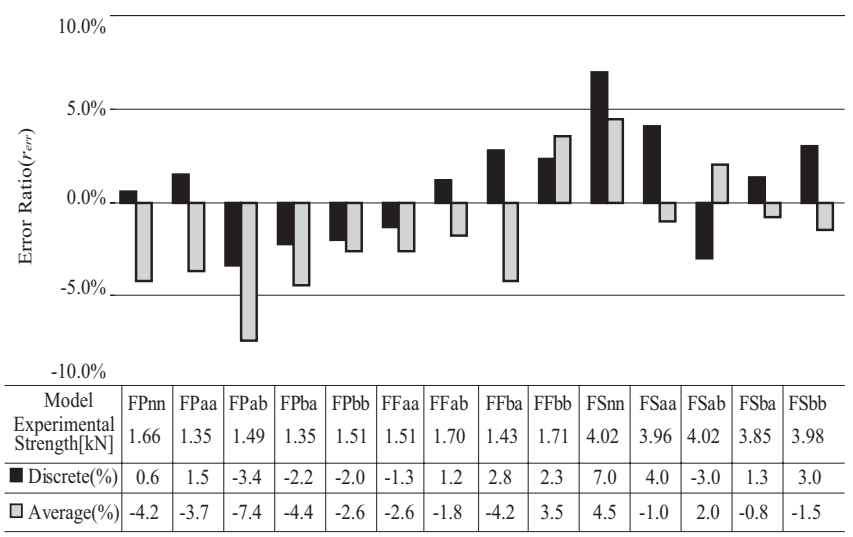

Fig. 8 Strength Error Ratio to Experimental Strength
実験 (太い実線) における荷重変位曲線を数值解 $\mathrm{D}$ ( 細い破線) お よび数值解 A( 細い実線) の結果と共に Fig.9 に示す。同図は、載荷 荷重と載荷点直下の鉛直方向変位の関係を示している。シート補 強無しの健全な供試体 FPnn を同図 (a) およびシート補強有りの健 全な供試体 FSnn を同図 (h) に示した。同図上段の 2 列目から修復 幅 $4 \mathrm{~mm}$ の場合を示し、同図下段の 2 列目から修復幅 $20 \mathrm{~mm}$ の場合 を示した。修復 P による場合を同図 $(b, c, i, j)$ 、修復 F による場合を 同図 $(d, e, k, l)$ 、修復 S による場合を同図 (f, g, m, n) にそれぞれ示し た。最初に実験值について考察する。シート補強無しの健全な供試 体 FPnn および修復 P による場合において、前述「4.2 数值解 S に おいて修復が耐力に及ぼす影響」と同様に、修復幅 $20 \mathrm{~mm}$ ( FPab, $\mathrm{FPbb}$ ) に比べて修復幅 4mm( FPaa, FPba ) の場合に若干の耐力低下 が確認でき、僅かな剛性低下も確認できる。次に、シート補強無し の健全な供試体 FPnn および゙修復 F による場合において、弾性範囲 内では全ての供試体がほぼ同一の挙動を示しているのに対して塑性 域で若干の相違が認められる。最後に、シート補強無しの健全な供 試体 FPnn と比較して、修復 S による供試体は耐力の大幅な増大が 示された。しかも、修復 S による供試体は、初期剛性が高く、最大 耐力までほぼ直線的な耐力の増大が示され、シート補強無しの供試 体と比べて広い弾性範囲が顕著に示されている。以上より、シート 補強を施した場合に、シェルの弾性設計の許容範囲を大幅に拡大で きる。なお、シート補強有りの健全な供試体 FSnn と比較して、X 方向の修復幅 $20 \mathrm{~mm}$ の FSab を除くと変形量の大幅な増大が示され ている。次に、実験值と数值解を比較すると、数值解 $\mathrm{A}$ と数值解 $\mathrm{D}$ の間に大きな相違は認められない。これは、両面型枠施工により施 工板厚の管理精度が高まったことによるものと考えられる。しかし、 修復 S の場合では、数值解 $\mathrm{D}$ と比較すると数值解 $\mathrm{A}$ の方が実験值 に対してさらに良い対応が確認できる。この理由は、シート補強に より施工板厚の変動による耐力への影響が緩和されたことによるも のと考えられる。

\section{5 ひび割れ形態}

実験におけるひび割れ図を上面と下面に分けて板厚の変動分布と

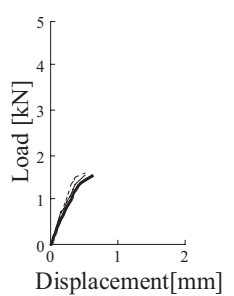

(a) FPnn

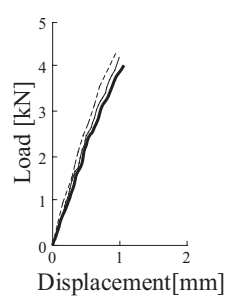

(h) FSnn

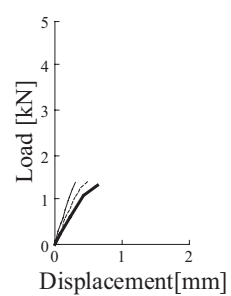

(b) FPaa

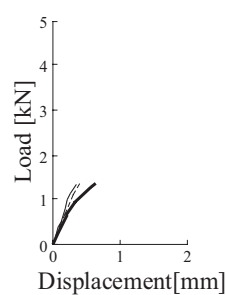

(i) FPab

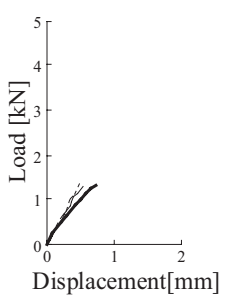

(c) $\mathrm{FPba}$

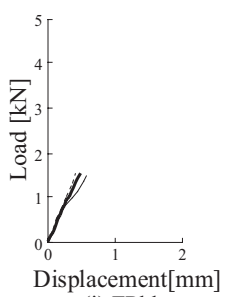

(j) FPbb

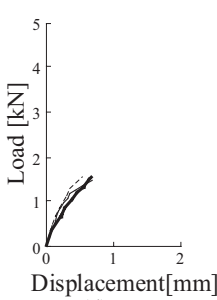

(d) FFaa

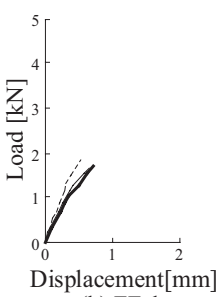

(k) FFab

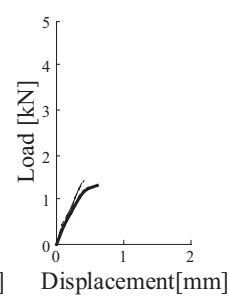

(e) $\mathrm{FFba}$

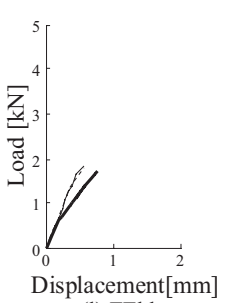

(1) FFbb

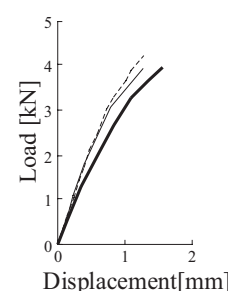

(f) FSaa

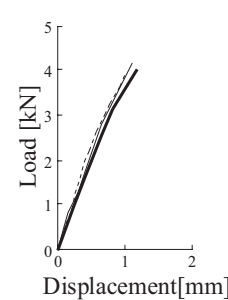

(m) FSab

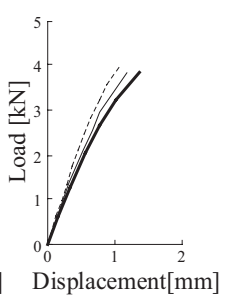

(g) FSba

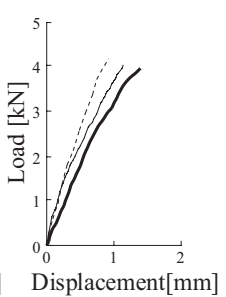

(n) FSbb

Experiment

Average

- Discrete

Fig. 9 Load vs. Displacement Curves 
共に Fig.10 に示す。なお、修復 S の場合において、同図に示した 各ひび割れ状態は、実験終了後炭素繊維シートを剥がして目視によ り確認したものである。この時、シート補強有りの場合、シート破 断は確認されていない。実大寸法では前述の Fig.7 の結果を考慮す ると、シート板厚比 $R_{t}$ の減少と共にシート耐力比が減少するため、 シート耐力比 $R_{t}$ が前述 $\lceil 4.2$ 数值解 $\mathrm{S}$ において修復が耐力に及ぼ す影響」で示した $R_{t B}$ より小さくなると、更にシート自体に加わる 負担は減少するものと考えられる。

修復 P によるいずれの供試体も健全な FPnn よりひび割れ量が多 く、しかもシェル下面における修復領域を結ぶ線上のひび割れが特 徵的である。修復幅の相違による影響に注目すると、X 方向および Y 方向の修復に対していずれも、修復幅の広い FPab および FPbb は 修復幅の狭い FPaa および FPba より、ひび割れ量が多いことが特徴 的である。修復 F の場合には、対応する修復 P の場合と比較して、 それぞれ載荷点からシェル面に広がる広範囲のひび割れが特徴的で ある。これらのひび割れの特徴はシート補強無しの健全な供試体 FPnn と比較して一層明確に示されている。加えて、修復 P の場合 と同様に、修復 $\mathrm{F}$ の場合は、修復領域を結ぶ線上のひび割れが特徴 的である。修復 $\mathrm{S}$ の場合は修復箇所および修復幅による影響が少な く、いずれも載荷点を中心とした円形および放射状の曲げひび割れ が特徵的である。FC-S 造のシート補強有りの健全な供試体 FSnn の
ひび割れは、修復 S による場合と比較して、若干ひび割れ量が少な いものの相互に類似しており、シート補強効果が明確に示されてい るものと考えられる。な押、文献 (21) の炭素短繊維混入量 4\%の場 合と比較すると、本研究の $2 \%$ の場合にひび割れ発生量は、増加傾 向にあることが示された。

「2. 実験の概要」で記述した通り、最大耐力経過後の脆性的な崩 落状態を回避するため、本研究の全供試体は、最大耐力経過後速や かに荷重を除荷している。本数值解析では、分布ひび割れモデルを 採用しており、ひび割れ幅が大きく進行した場合、即ち最大耐力経 過後のひび割れ幅増大および載荷点直下における㫟没破壊等の終局 状態のひび割れを正確に確認することは困難である。しかしながら、 本研究の最大耐力時の実験によるひび割れ形態並びに実験および数 值解析の荷重変位曲線から破壊メカニズムを考察すると、以下の点 を指摘することができる。Fig.10のシート補強を行った供試体は、 いづれも載荷点直下のめり込み破壊 (FSnn, FSba) および貫通破壊 (FSaa, FSab) である。即ち、シート補強もしくは修復 S を施した場 合、載荷点直下の破壊モードが卓越し、めり达み破壊では放射状の 亀裂が進行し、貫通破壊では載荷点近傍以外のひび割れは限定的で ある。シート補強無しの場合に、修復の無いFPnn およびX 方向に 修復を施した全ての供試体の破壊メカニズムは同図に示した通り、 いずれの供試体 (FPaa, FPab, FFaa, FFab) も載荷点を通る X 方向のひ

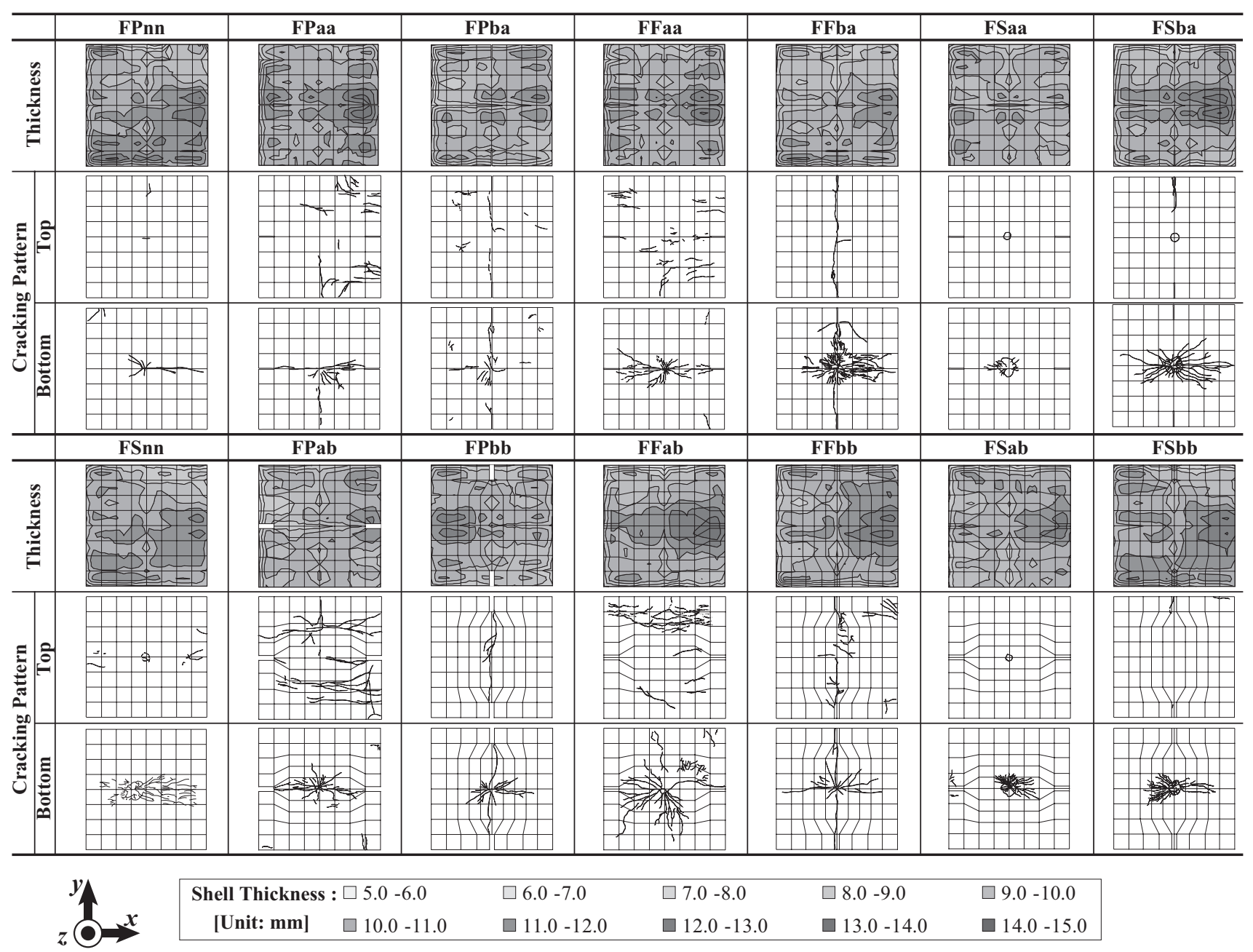

Fig. 10 Cracking Pattern at Ultimate Strength 
び割れ、即ちアーチ頂部の曲げひび割れが卓越し、シェルの分離破 壊への危険性を含んだ大規模な破壊に近づく傾向が示されている。 一方、シート補強無しで Y 方向に修復を施した全ての供試体の破壊 メカニズムは同図に示した通り、いずれの供試体 (FPba, FPbb, FFba, FFbb) も載荷点を通る Y 方向のひび割れが卓越し、シェルを分断す る大規模な破壊に向かう傾向が示されている。すなわち、炭素短繊 維補強コンクリート造では、最大耐力経過後、比較的脆性的な破壊 メカニズムを生じ易い。しかし、シート補強を行うことで脆性的な 破壊モードを防止し、さらに「4.4 荷重変位曲線」で前述した通り、 弾性範囲を大幅に拡げ、シェル耐力を増大することでシェルの安全 性に十分貢献できる。加えて、本実験においては、シートの破断は 皆無であり、そのためシート補強により炭素短繊維補強コンクリー ト造シェルの分離破壊および崩落的な破壊を防止する効果が示され たものと考えられる。ここで、炭素繊維シートによる破壊モードを 比較すると、修復の無い場合に、FSnn は、FPnn と比較して載荷点 裏面の限定的なひび割れ発生が特徴的である。さらに、修復 S の場 合に抢いても、シート補強による同様のひび割れ抑制効果が確認さ れた。これにより、本研究で対象とした修復領域に関して、シート 補強の有無による破壊モードの特徵は、ほぼ等しいことが示された。

\section{5. 結論}

小型実験供試体による載荷実験および数值解析より、対称な 2 箇 所の修復箇所を対象として 3 種の修復された FC 造円筒款の耐力と ひび割れ形態を検討した結果、以下の結論を得た。

1) 修復 $\mathrm{P} ・ \mathrm{~F} ・ \mathrm{~S}$ を対象として、板厚および材料定数を一定值に設 定した数值解 S と実験の耐力との整合性を耐力整合比の RMS を 用いて確認した。全面板厚比によるシェルの面内力 ( 板厚比に比 例 ) に対する耐力補正の有効性が示された。X方向の修復領域に 関して、シェル両端のアーチ効果 (板厚比に比例 )、および $\mathrm{Y}$ 方 向の修復領域に関して、シェル裙部両端の X 方向の曲げ抵抗 ( 板 厚比の二乗に比例 ) に対する耐力補正が有効であることをそれぞ れ確認した。なお、本研究の範囲では、全面板厚比 $T_{G A}$ による線 形補正 $E_{G A I}$ が最も有効であると考えられる。

2）炭素短繊維混入量 $4 \%$ の場合 (文献 (21)) と本研究の $2 \%$ の場合 の実験耐力を比較することにより、繊維混入量が $2 \%$ の場合にお けるシェル耐力は、シート補強無しの健全な供試体において 3 割 以下の耐力低下に抑制できることを確認した。

3）数值解 S の耐力から、各修復改善効果を明らかにした。修復 P の場合は、耐力低下を 1 割程度に抑制する効果を示した。修復幅 の広い場合に、その効果がより明確に示された。修復 F の場合は、 修復 P の場合と比較して若干の耐力改善を示した。修復 S の場合 は、全ての場合に 2.5 倍以上の耐力増加を示した。更に、シート 耐力比 $R_{p}$ が 1.5 倍以上で板厚 $48 \mathrm{~mm}$ 以下、 $R_{p}$ が 2.0 倍以上で板 厚 $23 \mathrm{~mm}$ 以下が示され、この板厚以下の場合には、繊維シート補 強により短期荷重の規模を長期荷重として取り扱うことができる 可能性を示した。

4) 実験值と数值解におけるシェル耐力の比較より、修復 P・F を施 した供試体に関して、実験值と施工板厚の変動を再現した数值解 $\mathrm{D}$ は良い対応を示した。修復 S による場合は、実験值と施工板厚 の平均值を採用した数值解 $\mathrm{A}$ と良い対応を示し、炭素繊維シート
補強による板厚変動の抑制効果を明示した。

5) 本研究の実験供試体のシェル板厚とシート板厚を変化させた場合 のシート補強によるシェル耐力効果の変動範囲を数值計算により 求め、シート板厚比 $R_{t}$ に対応するシート耐力比 $R_{p}$ の相関関係を 示した。

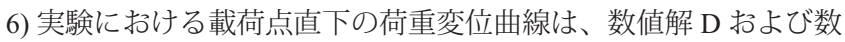
值解 A と比較的良い対応を示した。特に、修復 S による場合は、 シート補強により弾性範囲および而力を増大することで、シェル の弾性設計の許容範囲を大幅に増大できることを示した。

7) ひび割れ形態の比較により、修復 $P$ ・F・S によるひび割れ発生 の影響が、修復幅と修復箇所の関係と共に明確に示された。特に、 シート補強による影響は顕著であり、脆性的な破壊モードを防止 し、シェルの安全性に十分貢献できることを示した。

\section{謝辞}

本研究の一部は、財団法人大林都市研究振興財団の研究助成を受 けた成果であります。また、本論文の執筆にあたり貴重なご助言を 頂きました、川崎健二郎氏に深謝致します。

\section{参考文献}

1) 坪井善勝：曲面構造 シェル理論とその応用, 丸善, 1965.03

2) 加藤渉，本岡順二郎：プレストレストコンクリート円筒曲板の試作，日 本建築学会論文報告集, 第 66 号, pp.493-496, 1960.10

3)Isler, H: Generating Shell Shapes by Physical Experiments, IASS, Bulletin Vol.34, pp. 53- 63, 1993.04

4)Dulacska, E: Buckling of Reinforced Concrete Shells, ASCE, pp. 2381-2401, 1981.12

5) 皆川洋一: 裙梁を有する直交異方性円筒シェル屋根の解析解と静的挙動, 日本建築学会構造系論文集, 第 463 号, pp.75-84,1994.09

6) Scordelis, A: Nonlinear Material, Geometrical and Time-Dependent Analysis of Reinforced and Prestressed Concrete Shells, Proc. IASS, Madrid, pp.57-70, 1989.09

7) 武藤厚, 花井健吾, 舟崎孝介, 加藤史郎：一葉双曲面 $\mathrm{RC}$ 造冷却塔の 構造特性に及ぼす形状不整の影響の分析 - 実測された形状の再現モデ ルを用いた損傷・耐力評価 -, 日本建築学会構造系論文集，第 584 号， pp.103-110, 2004.10

8) 國枝治郎, 加藤史郎, 高山誠, 半谷裕彦, 真下和彦, 皆川洋一, 山田聖 志：鉄筋コンクリートシェル耐荷力実験資料集, 日本建築学会, 1993.03

9) 高山誠, 中村博志, 加藤史郎：形状初期不整を有する鉄筋コンクリート 円筒シェルの破壊性状と最大耐力に関する実験と数值解析の比較, 日本 建築学会構造系論文報告集，第 429 号,pp.111-124,1991.11

10) Domingo, A et al.: Design of a Thin Shell Steel Fiber Reinforced Concrete Hyper Roof, Proc. IASS 1999, Madrid, Volume I, A171-A179, 1999

11) 真下和彦, 小林 岡：点荷重を受ける開口部付き炭素短繊維補強コンク リート造円筒殼の耐力，日本建築学会構造系論文集，第 539 号,pp.79-86, 2001.01

12)Teng, J.G. and Lam, L: Compressive Behavior of Carbon Fiber Reinforced Polymer-Confined Concrete in Elliptic Columns, J of Structural Engineering, ASCE, pp.1535-1543, 2002.12

13) 川崎健二郎, 真下和彦: 集中荷重を受ける複合炭素繊維補強コンクリー 卜造円筒殼の耐力, 日本建築学会構造系論文集，第 592 号, pp.105-112, 2005.06

14) 川崎健二郎, 真下和彦 : 複合炭素繊維補強コンクリート造円筒款の耐力 ，破壊形態及び振動特性一集中荷重による破壊実験に対する検討一, 日本建築学会構造系論文集，第 609 号，pp.113-120, 2006.11

15) 田中正史，真下和彦，川崎健二郎：修復された鉄筋コンクリート造円筒 殼の耐力，構造工学論文集，Vol.54B, pp.289-294, 2008.03 
16) 秋浜繁幸, 未永龍夫, 坂野正：炭素瀻維を用いたセメント系複合体 (CFRC) の力学的性質に関する実験的研究, コンクリート工学, Vol.20, No.8, pp.75-84, 1982.08

17)Lim, T.Y., Paramasivam, P. and Lee, S.T: Bending Behavior of Steel- Fiber Concrete Beams, ACI Structural Journal, Vol.84, No.6, pp.524-536, Nov.-Dec. 1987.

18) 渡部憲, 白井伸明, 大岡督尚, 白都滋, 藤田敬：高勒性ビニロン短繊維 補強モルタル耐震壁の弾塑性挙動に関する基礎的研究, 日本建築学会構 造系論文集，第 559 号， pp.211-218, 2002.09

19) E, Hinton and D, R, J, Owen, : Finite Element Software for Plates and Shells, Pinerige Press, 1984
20) H.Kupfer, K. H. Hilsdorf and H. Rush: Behaviour of Concrete under Biaxial Stress, Proc. ACI, Vol.66, No.8, pp.656-666, Aug. 1969

21) 田中正史, 真下和彦, 川崎健二郎：前損傷および修復の有無による炭素 短繊維補強コンクリート造円筒殼の耐力と損傷形態変化, 東海大学紀要 工学部, Vol.47, No.1, pp.43-47, 2007.09

22) 鉄筋コンクリート構造計算基準・同解説：日本建築学会, 1999.

23) Felix Candela: Notes for History, The Development of Thin Shells in Mexico, IASS, Bulletin n.71, 72, pp. 27- 38, Sep. 1979

24) Alan Holgate: The Art of Structural Engineering, The Work of Jorg Schlaich and His Team, Edition Axel Menges, Stuttgart/ London, 1997

(2009年 2 月 9 日原稿受理, 2009 年 6 月 12 日採用決定) 